\title{
Laporan Kasus: Transarterial Chemoembolization (Tace) sebagai Terapi Pilihan pada Karsinoma Hepatoselular
}

\author{
Sherly Eva Wijayaningrum ${ }^{1 *}$, Firman P. Sitanggang ${ }^{1}$, Putu Patriawan ${ }^{1}$ \\ Departemen Radiologi Fakultas Kedokteran Universitas Udayana - RSUP Sanglah, \\ Denpasar-Bali ${ }^{1}$ \\ *e-mail: sherlyeva@yahoo.com
}

\begin{abstract}
Abstrak
Karsinoma hepatoselular (KSH) merupakan tumor primer hepar yang paling sering, dan masih menduduki 10 besar penyakit kanker terbanyak di Indonesia. KSH lebih sering terjadi pada lakilaki dan $90 \%$ kasus KSH berkembang pada latar belakang penyakit kronik hepar, dan biasanya berkorelasi dengan infeksi virus Hepatitis B (VHB) dan C (VHC). Terdapat berbagai pilihan terapi yang dapat diberikan pada pasien $\mathrm{KSH}$, namun pada pasien $\mathrm{KSH}$ stadium intermediate dan lanjut, terapi yang diberikan adalah terapi paliatif seperti transarterial chemoembolization (TACE) and sistemikkemoterapi. Seorang laki-laki usia 51 tahun dengan diagnosis KSH yang ditegakkan berdasarkan anamnesis, pemeriksaan fisik, radiologis, dan laboratorium, dirujuk ke departemen Radiologi Intervensi untuk dilakukan TACE. Pada evaluasi menyeluruh disimpulkan pasien sesuai dengan klasifikasi Barcelona Clinic Liver Cancer (BCLC) B. Pada pasien didapatkan adanya riwayat hepatitis $B$, ascites, albumin yang rendah, AFP yang sangat tinggi, dari CT Scan abdomen dengan kontras 3 fase, tampak ukuran massa yang cukup besar pada lobus kanan hepar, tidak tampak thrombus vena porta. TACE dilakukan dengan campuran doxorubicin 50 $\mathrm{mg}$ dan lipiodol, serta diberikan gel foam sebagai embolan. Evaluasi CT Scan pada mingguke-8 pasca TACEC tampak area nekrosis yang meluas tanpa perubahan ukuran massa. Perluasanarea nekrosis merupakan salah satu patokan stadium KSH pada pasien ini, sesuai dengan kriteria respon parsial. TACE merupakan terapi paliatif pilihan sesuai dengan rekomendasi BCLC B. Evaluasi kinerja TACE lebih optimal dengan menilai ukuran area nekrosis dibandingkan ukuran masa.
\end{abstract}

Kata Kunci: TACE, karsinoma hepatoselular (KSH), BCLC, radiologi intervensi, CT Scan

\section{A Case Report: Transarterial Chemoembolization (Tace) as the Treatment of Choice for Hepatocellular Carcinoma}

\begin{abstract}
Hepatocellular carcinoma (HCC) is the most common primary tumor of the liver and occupies the top 10 most cancers in Indonesia. Men are likely to develop HCC, and $90 \%$ cases of HCC develop in the background of chronic liver disease, which associates with hepatitis $B$ and $C$ virus infection. There are numerous treatment options for HCC, however in intermediate-advanced stage, palliative treatment such as transarterial chemoembolization (TACE) and systemic chemotherapy are the management of choice. A 51 years old male with HCC based on history, physical examination, radiology and laboratory result was referred to interventional radiology department for TACE consideration. Barcelona Clinic Liver Cancer (BCLC) B was concluded in this patient after thorough evaluation. There was history of hepatitis $B$ infection, ascites, low albumin level, high AFP, and from Abdominal CT Scan with contrast showed large lobulated
\end{abstract}


Laporan Kasus: Transarterial Chemoembolization (Tace) Sebagai Terapi Pilihan pada...

Sherly Eva Wijayaningrum, Firman P. Sitanggang, Putu Patriawan

mass on the right lobe, without evidence of portal vein thrombosis. TACE was eligible and done using mixed of doxorubicin $50 \mathrm{mg}$ and lipiodol, and embolization using gel foam. After 8 weeks CT evaluation was done and showed increase area of tumor necrosis, while tumor size was stable. Necrosis area expansion is the standard used for evaluating this patient which fell into partial response criteria. TACE is a palliative therapy of choice in accordance with BCLC B recommendation. Evaluation of TACE performance is more optimal by assessing the size of necrosis area compared to mass measurement.

Keywords: TACE, hepatocellular carcinoma (HCC), BCLC, interventional radiology, CT Scan

\section{PENDAHULUAN}

Karsinoma hepatoselular (KSH) merupakan tumor primer hepar yang paling sering berkontribusi sebesar $80 \%$ dari seluruh tipe kanker hati, serta menduduki peringkat ke- 6 kanker tersering di dunia (Zhu et al, 2016) dan termasuk dalam 10 besar penyakit kanker terbanyak di Indonesia.

KSH lebih sering terjadi pada lakilaki, dan pada Asia-pasific termasuk Negara Indonesia, KSH 4x lipat lebih sering pada laki-laki dibanding perempuan (Zhu et al, 2016). Sekitar $70-90 \%$ pasien dengan $\mathrm{KSH}$ memiliki riwayat penyakit kronis hepar dengan factor risiko mayor seperti virus Hepatitis B (VHB) dan C (VHC), penyakit hepar akibat alcohol dan steatohepatitis non-alkohol. Faktor risiko lainnya juga dapat berkontribusi pada kejadian KSH seperti, makanan yang terkontaminasi aflatoksin, diabetes mellitus, obesitas, penyakit metabolic atau keturunan seperti hemokromatosis. (Zhang et al, 2005)

Sebesar $50-80 \%$ VHB bertanggung jawab terhadap kejadian KSH. Hubungan infeksi kronik VHB dan KSH diketahui oleh karena adanya hepatitis B e-antigen (HBeAg), level serum alanin, $\downarrow$ aminotransferase, dan sirosis hepar. Prediktor terjadinya KSH pada pasien dengan infeksi VHB adalah dengan level VHB DNA, dikatakan risiko $\mathrm{KSH}$ terjadi apabila terdapat level HBV DNA $>2,000 \mathrm{IU} / \mathrm{mL}$ setara dengan 10,000 kopi/mL (Chen et al, 2009; Zhu et al, 2016)

Infeksi VHC menyebabkan inflamasi kronik, proliferasi, dan sirosis hati. Sirosis hati akibat VHC dapat meningkatkan risiko KSH, risikonya bervariasi bergantung dengan derajat fibrosis hati akibat infeksi VHC (Chen et al, 2009).

Makanan yang mengandung aflatoksin B1 dapat ditemukan pada makanan tradisional seperti biji-bijian, jagung, singkong, kacang tanah, dan kacang kedelai yang difermentasi. Aflatoksin B1 dapat menyebabkan mutasi DNA, terutama gen p53 yang merupakan gen penekan tumor, sehingga menurunkan gen p53 sebesar 30-60\%, dan 
meningkatkan terjadinya KSH. (Zhang et al, 2005)

$\begin{array}{ccc}\text { Konsumsi } & \text { alcohol yang } \\ \text { berkepanjangan juga merupakan } & \text { risiko }\end{array}$

KSH. Konsumsi sebesar 50-70 g/hari dapat meningkatkan terjadinya sirosis yang merupakan faktor risiko terjadinya $\mathrm{KSH}$. Penyakit metabolic seperti diabetes mellitus juga merupakan faktor risiko penting terjadinya penyakit liver kronis dan $\mathrm{KSH}$, yang mungkin difasilitasi oleh terbentuknya perlemakan hati dan steatohaptitis non-alkoholik. (Cartier and Aube, 2014; Duseja, 2014)

Diagnosis KSH dapat ditegakan melalui anamesis terdapatnya faktor risiko mayor KSH seperti yang telah dipaparkan diatas. Selain itu pemeriksaan serum marker alfa-fetoprotein (AFP) dengan pemeriksaan ultrasonografi (USG) dan/atau CT Scan dapat membantu mengkonfirmasi diagnosis.(Cartier and Aubé, 2014) Serum AFP lebih dari 400-550 $\mathrm{ng} / \mathrm{mL}$ merupakan nilai diagnostik KSH.(Colombo, 2001) Pada KSH biasanya pasien bahkan memiliki serum AFP yang sangat tinggi (> $100000 \mathrm{ng} / \mathrm{ml}$ ), dan sekitar $30 \%$ dapat memiliki serum AFP yang normal atau rendah. (Cartier and Aube, 2014)

USG dapat membantu pemeriksaan $\mathrm{KSH}$ terutama dalam mengevaluasi vaskularisasi tumor serta vena porta. Ada atau tidaknya thrombus vena porta, ada atau tidaknya fistula pada vascular di hati, serta membedakan invasi tumor atau thrombus pada vena porta menggunakan USG Doppler merupakan penentu terapi pada pasien KSH. CT Scan abdomen dengan kontras 3 fase telah rutin dilakukan sebagai pencitraan diagnostic tumor di hati. KSH yang mendapatkan vaskularisasi dari arteri hepatica akan menunjukkan penyengatan pada fase arteri 2-40 detik setelah kontras diinjeksikan, dan pada fase vena penyengatan langsung berkurang, dan semakin berkurang pada fase delay, fenomena ini disebut juga rapid wash in dan wash out yang merupakan karakterisitik KSH.(Cartier and Aube, 2014) Selain karakteristik penyengatannya, gambaran KSH biasanya heterogen, memiliki garis fibrosa intratumoral (mosaic sign), nekrosis, metamorphosis lemak, atau kalsifikasi. Nodul satelit didekat tumor primer juga dapat ditemukan. MRI juga memberikan gambaran rapid wash in dan wash out, dengan restricted diffusion pada diffusion weighted imaging (DWI). (Cartier and Aubé, 2014); (Chanyaputhipong et al, 2011) MRI dapat mendeteksi lebih lanjut terutama penggunaan kontras yang spesifik hepatosit seperti gadoxetate acid dan gadobenate dimeglumin meningkatkan spesifisitas dan sensitivitas deteksi kelainan 
Laporan Kasus: Transarterial Chemoembolization (Tace) Sebagai Terapi Pilihan pada...

Sherly Eva Wijayaningrum, Firman P. Sitanggang, Putu Patriawan

hati pada MRI. (Chanyaputhipong et al, 2011)

BCLC merupakan klasifikasi KSH yang digunakan untuk menentukan terapi pada setiap stadium. Selain itu yang termasuk pada klasifikasi system BCLC adalah perkiraan prognosis, ekstensi tumor, fungsi hati menggunakan Child-Pugh (table 1) dan status fisik sesuai dengan Eastern Cooperative Oncology Group (ECOG). Terdapat 5 kategori pada BCLC yakni $0, A$, B, C, dan D, dimana BCLC 0 adalah stadium sangat awal, dengan child pugh A, ukuran tumor $<2 \mathrm{~cm}$, asimptomatis dan tidak ada invasi vascular atau nodul satelit. BCLC A adalah staium awal, termasuk child pugh A/B pada pasien dengan tumor soliter tanpa batasan ukuran atau 2-3 tumor dengan ukuran $<3 \mathrm{~cm}$. BCLC B merupakan stadium intermediate, pada pasien dengan Child - pugh $A / B$, tumor multiple tanpa invasi vascular atau metastase ekstrahepar. Pasien dengan Child-pugh A/ $B$, dengan invasi tumor ke vascular atau metastase ekstrahepatik dengan statis fisik 1-2 termasuk pada BCLC C, sedangkan stadium terminal BCLC D merupakan pasien dengan Child-Pugh $\mathrm{C}$ dengan status fisik > 2. (Duseja, 2014; Kinoshita et al, 2015)

Pada stadium BCLC 0 dan A, terapi kuratif seperti operasi reseksi, transplant hati, dan ablasi dapat dipertimbangkan. Sedangkan untuk pasien dengan BCLC B, terapi paliatif dengan TACE direkomendasikan Kemoterapi dengan sorafenib dapat diberikan sebagai terapi paliatif untuk BCLC C, sedangkan terapi suportif masih dapat diberikan pada pasien stadium terminal (BCLC D) dengan harapan hidup lebih dari 3 bulan.(Duseja, 2014; Kinoshita et al, 2015)

\begin{tabular}{|c|c|c|c|}
\hline \multicolumn{4}{|c|}{ Tabel 1. Skor Child-Pugh(Duseja, 2014; Kinoshita et al, 2015) } \\
\hline Faktor & 1 poin & 2 poin & 3 poin \\
\hline Total bilirubin $\mathrm{mg} / \mathrm{dl}$ & $<2$ & $2-3$ & $>3$ \\
\hline Serum albumin $\mathrm{g} / \mathrm{dL}$ & $>3.5$ & $2.8-3.5$ & $<2.8$ \\
\hline PT INR & $<1.7$ & $1.71-2.30$ & $>2.30$ \\
\hline Ascites & Negatif & Ringan & Sedang-berat \\
\hline Ensefalopati hepatikum & Negatif & Derajat I-II & Derajat III-IV \\
\hline & A & B & $\mathbf{C}$ \\
\hline Total poin & $5-6$ & $7-9$ & $10-15$ \\
\hline
\end{tabular}

\section{LAPORAN KASUS}

Seorang laki-laki usia 51 tahun datang ke rumah sakit dengan keluhan kuning, nyeri perut kanan atas, disertai berat badan yang menurun. Pasien dengan riwayat penyakit Hepatitis B kronis positif.
Berdasarkan pemeriksaan fisik, radiologis, dan laboratorium, pasien didiagnosa dengan KSH dan dirujuk ke departemen Radiologi Intervensi untuk dilakukan TACE.

Pada pemeriksaan fisik, pasien tampak sadar penuh, aktif, dapat 
menjalankan aktivitas sehari-hari tanpa restriksi, kurus serta ikterik. Pemeriksaan laboratorium didapatkan total bilirubin $1.90 \mathrm{mg} / \mathrm{dL}$, albumin $3.50 \mathrm{~g} / \mathrm{dL}$, serum kreatitinin $2 \mathrm{mg} / \mathrm{dL}$, rasio PPT INR 1.03, SGOT 113.2 u/l, SGPT $41.5 \mathrm{U} / \mathrm{L}$, dan kadar alpha fetoprotein (AFP) $450 \mathrm{ml} / \mathrm{IU}$. Pada pemeriksaan CT Scan tampak massa batas tegas tepi lobulated pada lobus kanan hepar dengan ukuran terbesar 12.7 x 10.5 x
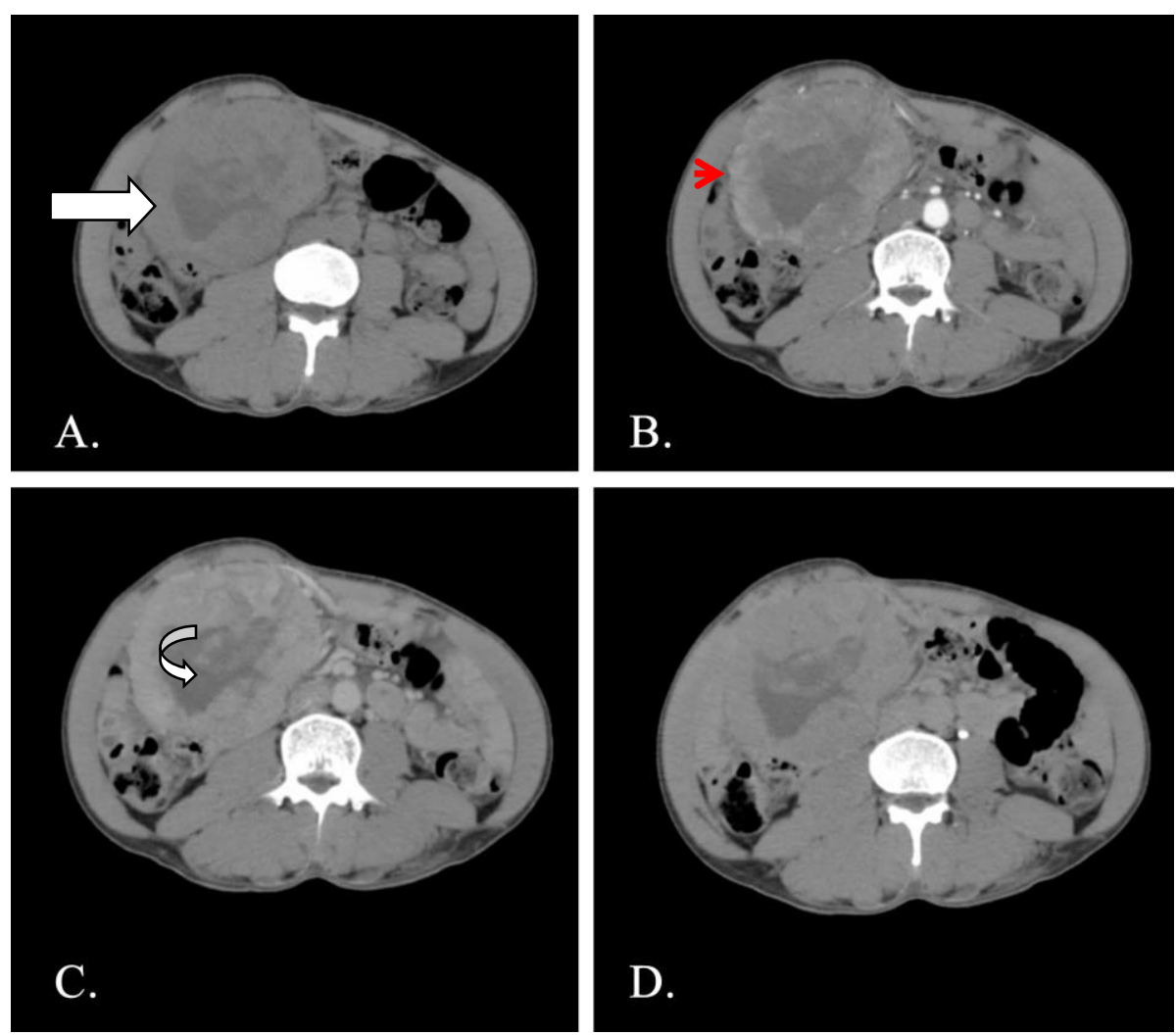

Gambar 1. CT Scan Abdomen 3 fase pada KSH. Massa batas tegas tepi lobulated (panah putih), yang tampak isodense dengan komponen nekrotik sentral (panah lengkung) pada CT Scan sebelum kontras (A), yang tampak hipervaskularisasi dan penyengatan bagian solidnya pada fase arteri (panah merah)

(B), dengan penurunan densitas pada fase vena (C) dan semakin menurun pada fase delay (D), mengesankan rapidwash in dan wash out.

Dari seluruh pemeriksaan yang telah dilakukan disimpulkan pasien sesuai dengan $B C L C B$, dengan status fisik derajat
0 , child-pugh A, tumor multinoduler dengan ukuran yang cukup besar tanpa tervisualisasinya thrombus vena porta. 


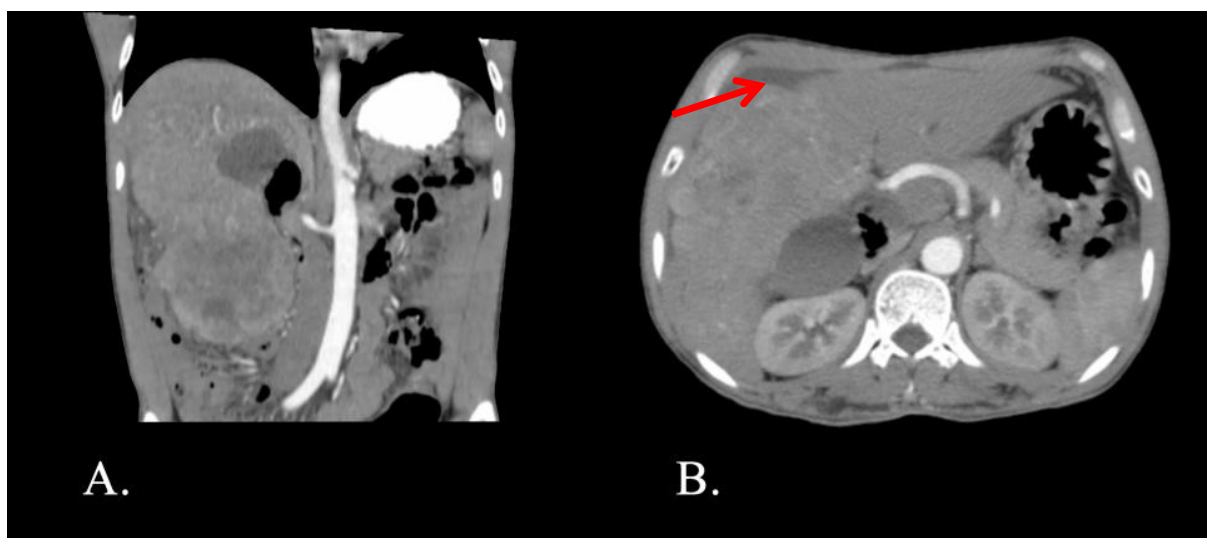

Gambar 2. A) Potongan koronal menunjukkan multinodular massa yang meluas pada segmen VI-VII lobus kanan hepar, serta desakan massa pada struktur disekitarnya. B) Tampak densitas cairan perihepatal minimal (panah merah).

TACE dilakukan melalui arteri hepatica kanan segmen VI-VII, diinjeksikan femoralis, pada angiografi tampak larutan campuran doxorubicin $50 \mathrm{mg}$ dan hipervaskularisasi tumor dengan gambaran lipiodol $5 \mathrm{cc}$ kemudian diberikan embolan blushing yang berasal dari cabang arteri gel foam pada pangkal arteri. (Gambar 3)

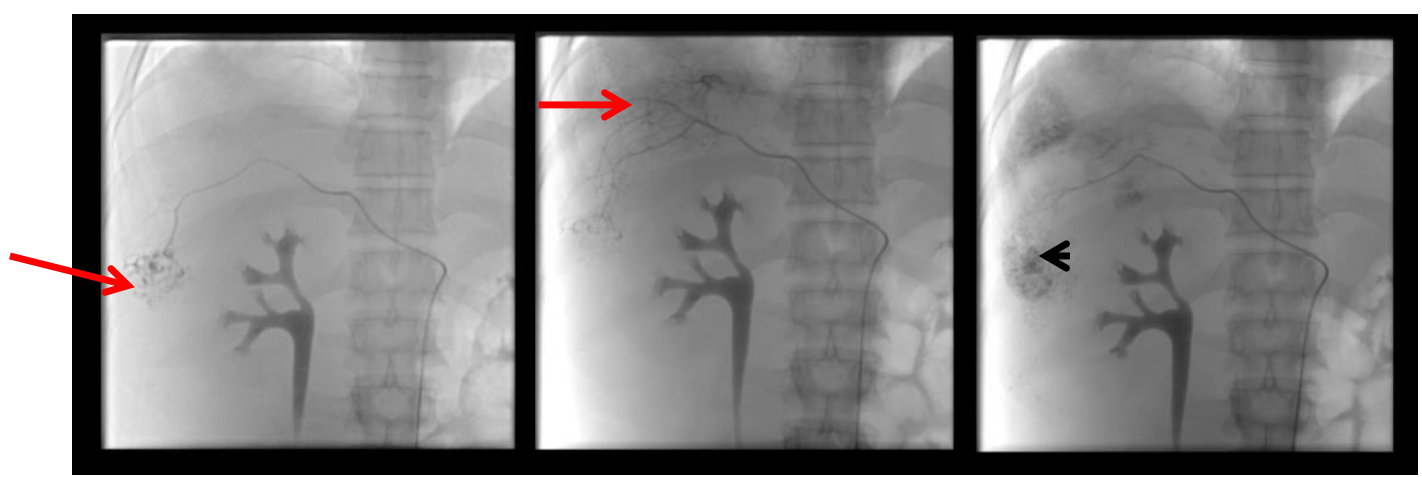

A

B

C

Gambar 3. A) Tampak hipervaskularisasi/tumor blush pada segmen VI lobus kanan (panah merah) dan B) segmen $V$ lobus kanan hepar (panah merah). C) Tampak gambaran larutan kemoterapi dengan lipiodol yang telah diinjeksikan (panah hitam).

Evaluasi CT Scan abdomen 8 minggu setelah tindakan tidak menunjukkan perubahan ukuran yang signifikan namun tampak perluasan area nekrosis, disertai penurunan kadar AFP menjadi $300 \mathrm{ml} / \mathrm{IU}$, total bilirubin $1.2 \mathrm{mg} / \mathrm{dL}$, albumin 3.10 $\mathrm{g} / \mathrm{dL}$.
Melihat respon TACE yang baik pada tumor, maka tindakan TACE dipertimbangkan untuk dilakukan kembali pada pasien agar mendapatkan hasil yang lebih maksimal. 


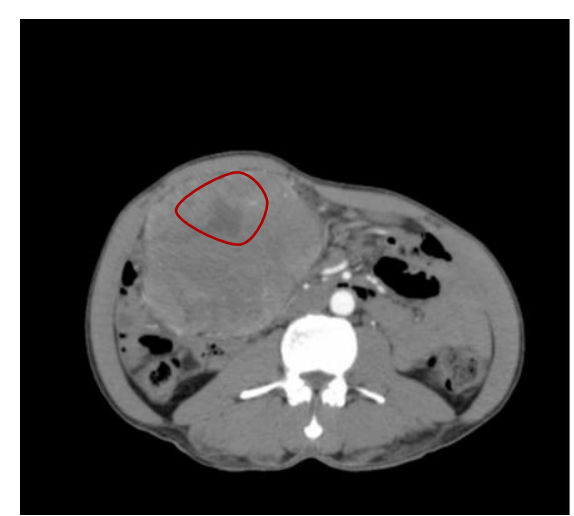

A

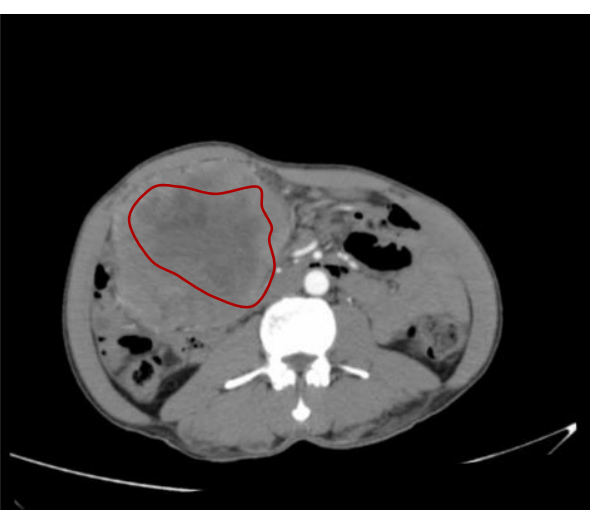

B

Gambar 4. CT Scan Abdomen sebelum TACE (A) dan pada minggu ke-8 sesudah TACE (B), tampak meluasnya area nekrotik lebih dari 50\% area nekrotik sebelum TACE (lingkar merah), serta menurunnya hipervaskularisasi pada komponen solid tumor, yang tampak pada gambar sebelum TACE (panah hitam) dan mengabur pada setelah TACE.

\section{DISKUSI}

KSH merupakan kanker tersering ke6 yang didiagnosis dan kanker ke-3 penyebab kematian di seluruh dunia. (Zhu et al, 2016) Terapi KSH lokoregional seperti TACE, merupakan terapi kombinasi injeksi kemoterapi selektif dengan embolisasi, telah dianjurkan untuk pasien dengan ukuran tumor yang besar atau multifocal atau tumor yang tidak dapat direseksi, oleh karena dapat memperpanjang harapan hidup dan prognosis pasien KSH stadium intermediate-lanjut. (Sun et al, 2017)

Melalui klasifikasi BCLC, pasien tergolong $B C L C B$ yang memang disarankan menjalani terapi paliatif yakni TACE. Pada evaluasi CT Scan dan pemeriksaan fisik, tidak tampak tanda-tanda thrombus vena porta yang merupakan kontraindikasi TACE, walaupun beberapa penelitian telah membuka batasan tersebut agar tetap dapat dilakukan TACE, namun hasilnya masih dalam penelitian. Hasil pemeriksaan laboratorium pasien masih masuk dalam kriteria indikasi TACE, tidak ditemukan peningkatan bilirubin total $>3 \mathrm{mg} / \mathrm{dL}$, lactate dehidrogenasi $>425 \mathrm{U} / \mathrm{I}$, aspartate aminotransferase lebih dari $5 x$ batas atas normal. (Liapi and Geschwind, 2011) Kontraindikasi absolut juga tidak ditemukan pada pasien seperti gangguan perdarahan, leukopenia, insufisiensi kardiak dan ensefalopati hepatikum. (Lencioni et al, 1993; Piscaglia and Ogasawara, 2018) Pasien memiliki kadar serum kreatinin yang cukup tinggi, oleh karena itu pemilihan obat kemoterapi harus dievaluasi serta penggunaan kontras harus diwaspadai.

$$
\text { Konvensional TACE dilakukan }
$$
menggunakan injeksi agen kemoterapi dengan lipiodol serta agen embolan pada 
Laporan Kasus: Transarterial Chemoembolization (Tace) Sebagai Terapi Pilihan pada... Sherly Eva Wijayaningrum, Firman P. Sitanggang, Putu Patriawan

arteri yang suplai tumor tersebut. Obat kemoterapi yang biasanya diberikan adalah kombinasi doxorubicin $50 \mathrm{mg}$ dan cisplatin $100 \mathrm{mg}$ yang didilusi pada kontas water soluble, namun penggunaan cisplatin tidak disarankan pada pasien dengan serum kreatinin yang meningkat seperti pada pasien ini, oleh karena dapat mengakibatkan nefrotoksisitas. (Miller et al, 2010; Liapi and Geschwind, 2011)

Saat ini terdapat obat kemoterapi tace drug eluting beads (DEB) TACE dimana obat kemoterapi tersebut dicampur dengan manik-manik yang dapat larut, sehingga dapat memfasilitais pemberian kemoterapi sekaligus dengan embolisasi dengan pelepasan obat sedikit demi sedikit (terkontrol) yang kontinyu (Forner et al, 2009). Pada beberapa studi mengemukakan penggunaan DEB TACE dapat membantu menurunkan progresifitas tumor, menurunkan ukuran tumor, sehingga pasien dapat masuk dalam kriteria untuk dilakukan terapi definitif lainnya seperti transplantasi (Forner et al, 2009). Sayangnya penggunaan DEB TACE sangat terbatas di Indonesia, serta harga yang mahal.

Evaluasi respon terapi berdasarkan ukuran seperti pada kriteria response evaluation criteria in solid tumors (RECIST) merupakan indikator yang kurang optimal dalam memprediksi hasil terapi pasien dengan TACE (Vincenzi et al, 2015). Forner et al mengemukakan bahwa RECIST melewatkan semua respon komplit dan menurunkan ekspektasi sejauh mana respon parsial tumor dengan adanya nekrosis jaringan (Forner et al, 2009; Najmi Varzaneh et al, 2018). Kemanjuran antikanker pada TACE dinilai lebih baik menggunakan viabilitas daripada penilaian ukuran tumor, sehingga European Association for the Study of Liver (EASL) dan modifiedRECIST (mRECIST), menggunakan penilaian respon secara kuantifikasi area viabilitas tumor melalui pemeriksaan radiografi dengan kontras (Vincenzi et al, 2015; Sato et al, 2013)

Akumulasi retensi lipiodol merupakan biomarker tumor nekrosis, sedangkan tumor yang menyengat menggambarkan tumor yang masih viable. Evaluasi pasca TACE dilakukan pada paling tidak 7 minggu setelah prosedur untuk meluruhkan larutan yang diinjeksikan, apabila CT Scan dilakukan sebelum larutan tersebut menghilang maka akan tampak banyak artifak yang muncul pada gambar CT Scan akibat retensi lipiodol. Oleh karena itu pada pasien dilakukan evaluasi pasca TACE pada minggu ke 8 (1,5 bulan pasca TACE) (Najmi Varzaneh et al, 2018). Sesuai dengan studi sebelumnya yang menunjukkan hasil respon terapi dimana pasien ini tidak memiliki perbedaan ukuran 
tumor, namun memiliki perluasan area nekrosis pada tumor yang diinjeksi dengan agen kemoterapi dan lipiodol. Penggunaan embolan seperti gel foam, merupakan agen embolan yang temporer untuk menahan obat kemoterapi tersebut agar dapat bekerja maksimal serta mengoklusi aliran darah tanpa menyebabkan oklusi total.

Kriteria mRECIST untuk respon komplit adalah tidak tampak penyengatan arteri intratumoral pada seluruh target lesi, respon parsial dinilai apabila terdapat penurunan lebih dari $30 \%$ diameter total dari target lesi yang viable (penyengatan pada fase arteri). Sedangkan pada kriteria EASL, respon komplit adalah tidak tampaknya lesi yang viable (penyengatan pada fase arteri), sedangkan respon parsial adalah penurunan sebesar $50 \%$ total diameter target lesi yang viable. (Vincenzi et al, 2015) Pada kasus diatas respon terapi adalah respon parsial oleh karena adanya pengurangan diameter total lesi yang viable.

\section{KESIMPULAN}

TACE merupakan terapi locoregional pilihan dalam menangani $\mathrm{KSH}$ stadium intermediate hingga lanjut. Saat ini, bahkan banyak studi yang telah meneliti penggunaan terapi TACE pada stadium awal bahkan stadium paling akhir pada pasien KSH, dimana TACE memberikan hasil yang lebih baik pada pasien-pasien KSH. Evaluasi TACE menggunakan perluasan area nekrosis merupakan indikator yang optimal sesuai dengan kriteria yang telah dimodifikasi yakni mRECIST dan EASL.

\section{DAFTAR PUSTAKA}

Cartier V and Aube C, 2014. Diagnosis of hepatocellular carcinoma, Diagnostic and Interventional Imaging. 95(7-8): 709-719.

Chanyaputhipong J, Low SCA, and Chow PKH, 2011. Gadoxetate AcidEnhanced MR Imaging for HCC: A Review for Clinicians. International Journal of Hepatology. 2011: 1-13.

Chen CJ, Yang HI, and Iloeje UH, 2009. Hepatitis B virus DNA levels and outcomes in chronic hepatitis B. Hepatology. 49(55).

Colombo M, 2001. Screening for cancer in viral hepatitis. Clinics in Liver Disease. 5(1): 109-122.

Duseja A, 2014. Staging of Hepatocellular Carcinoma. Journal of Clinical and Experimental Hepatology. 4: S74S79.

Forner A, Ayuso C, Varela M, Rimola J, Hessheimer AJ et al, 2009. Evaluation of tumor response after locoregional therapies in 
Laporan Kasus: Transarterial Chemoembolization (Tace) Sebagai Terapi Pilihan pada... Sherly Eva Wijayaningrum, Firman P. Sitanggang, Putu Patriawan

hepatocellular carcinoma: Are response evaluation criteria in solid tumors reliable?. Cancer. 115(3): 616-623.

Kinoshita A, Onoda H, Fushiya N, Koike K, Nishino H, Tajiri H, 2015. Staging systems for hepatocellular carcinoma: Current status and future perspectives. World Journal of Hepatology. 7(3): 406-424.

Lencioni R, Petruzzi P and Crocetti L, 1993. Chemoembolization of Hepatocellular Carcinoma With Doxirubicin-Ethiodol'. Investigative Radiology. 28(12): 1185.

Liapi E and Geschwind JFH, 2011. Transcatheter Arterial chemoembolization for liver cancer: Is it time to distinguish conventional from drug-eluting chemoembolization?'.

CardioVascular and Interventional Radiology. 34(1): 37-49.

Miller RP, Tadagavadi RK, Ramesh G, and Reeves WB, 2010. Mechanisms of cisplatin nephrotoxicity. Toxins. 2(11): 2490-2518.

Najmi Varzaneh F, Pandey A, Aliyari Ghasabeh M, Shao N, Khoshpouri P et al, 2018. Prediction of post-TACE necrosis of hepatocellular carcinoma usingvolumetric enhancement on MRI and volumetric oil deposition on
$\mathrm{CT}$, with pathological correlation. European Radiology. 28(7): 30323040.

Piscaglia F and Ogasawara S, 2018. Patient Selection for Transarterial Chemoembolization in Hepatocellular Carcinoma: Importance of Benefit/Risk Assessment'. Liver Cancer. 7(1),: 104-119.

Sato $Y$, Watanabe $H$, Sone $M$, Onaya $H$, Sakamoto $\mathrm{N}$ et al, 2013. Tumor response evaluation criteria for $\mathrm{HCC}$ (hepatocellular carcinoma) treated using TACE (transcatheter arterial chemoembolization): $\quad$ RECIST (response evaluation criteria in solid tumors) version 1.1 and $\mathrm{mRECIST}$ (modified RECIST): JIVROSG-0602'. Upsala Journal of Medical Sciences. 118(1): 16-22.

Sun HL, Ni JY, Jiang XY, Chen D, Chen YT, and $\mathrm{Xu} \mathrm{LF}, 2017$. The effect of lipiodol deposition in HCC after TACE on the necrosis range of PMCT. OncoTargets and Therapy. 10: 38353842.

Vincenzi B, Di Maio M, Silletta M, D'Onofrio L, Spoto C et al, 2015. Prognostic relevance of objective response according to EASL criteria and mRECIST criteria in hepatocellular carcinoma patients treated with 
ISSN 1978-2071 (Print); ISSN 2580-5967 (Online) Jurnal IImiah Kedokteran Wijaya Kusuma 9(1): 49-59, Maret 2020

loco-regional therapies: A literaturebased meta-analysis. PLOS ONE. 10(7): 1-12.

Zhang YJ, Chen Y, Ahsan H, Lunn RM, Chen SY et al, 2005. Silencing of glutathione S-transferase P1 by promoter hypermethylation and its relationship to environmental chemical carcinogens in hepatocellular carcinoma. Cancer Letters. 221(2): 135-143.

Zhu RX, Seto WK, Lai CL, Yuen MF, 2016. Epidemiology of hepatocellular carcinoma in the Asia-Pacific region. Gut and Liver. 10(3): 332-339. 